\title{
LEGAL AND ETHICAL GROUNDS OF PROFESSIONAL SECRECY OF A LAWYER IN SELECTED EUROPEAN UNION COUNTRIES AND IN THE UNITED STATES OF AMERICA
}

\author{
Paula Maria Biatkowska*
}

\begin{abstract}
The subject of the article is professional secrecy in practicing the legal profession in American law, with the indication of some differences resulting from separate laws of different states, and in the European Union - taking into account a few exemplary countries. Its sources were described - both legal and ethical, as well as the definition and construction. Confidentiality has been included in the objective and subjective aspect, taking into account different views in the doctrine as to its scope. Bearing in mind the basic right from which professional secrets derive - the right to privacy - the article also includes some of its aspects related to confidentiality.
\end{abstract}

Keywords: right to privacy, professional secrecy, confidentiality

The role of professional secrecy reflects the importance of privacy and discretion in social life. In today's globalized world and the rapid development of technology, information - the flow of which is exceptionally efficient - and its non-disclosure aspect are becoming increasingly challenging. This pace should be compatible with the pace of change of law.

* Dr. Paula Maria Białkowska, Assistant Professor, Faculty of Law and Administration, University of Lodz; correspondence address: Romanowska $55 \mathrm{H}$, apartment no. 66, 91-174 Lodz, Poland; e-mail: pbialkowska@wpia.uni.lodz.pl; https://orcid.org/ 0000-0002-4639-3001. 
Jurisdictions in the United States and Europe varies essentialy in their approach to the privilege afforded to attorneys to shield the disclosure of confidential information related to the lawyer-client relationship. The adequate protection of clients interest, especially in times of multilateral agreements and international agreements, requires a proper understanding of the differences between privilege rules in the US and the EU.

The aim of the article is to present the institution of legal professional secrecy in the legal systems of the United States and the European Union - in general, and to outline the differences and possible similarities in the structure of this issue. The essential areas are: the subject, the object, the way in which the secrecy binds the parties and the duration of the binding. The combination of the above issues results in an attempt to assess the legal legitimacy of professional secrecy using, in particular, the dogmatic and legal method. The Polish legal system has been deliberately excluded from consideration, as it will be the subject of a separate publication.

\section{INTRODUCTION}

The basic element of professional secrecy is information. According to the Merriam-Webster Dictionary information is knowledge obtained from investigation, study, or instruction, or something (such as a message, experimental data, or a picture) which justifies change in a construct (such as a plan or theory) that represents physical or mental experience or another construct ${ }^{1}$. There is no legal definition of information in the legislation. However, it appears in the context of public or classified information, which is related in turn to the principle of openness. These definitions can only serve as a guide to the discussion of professional secrecy. In the abovementioned contexts, the information is held by the state and its organs, and the laws, the subject of which they constitute, define the limits of their availability to the citizen. In the context of professional secrecy, the information is, in some measure, the property of the citizen, and therefore the individual - in this case the representative of the profession of public

1 https://www.merriam-webster.com/dictionary/information, accessed February 22, 2021. 
trust or his client - consequently the guarantees of his protection will be contained in other acts. It seems that everyone should understand a secret in an intuitive way, and although it probably is, its precise definition is necessary for the effective protection of the right to privacy.

\section{LEGAL AND ETHICAL GROUNDS OF PROFESSIONAL SECRECY OF A LAWYER IN SELECTED EUROPEAN UNION COUNTRIES}

The concept of professional secrecy in the practice of law in the European Union is that a person who needs professional legal care must be sure that his or her legal affairs will not be disclosed to third parties and that the information will not be used against this entity. Individuals looking for a legal representative will feel free to pass on relevant information, only if the confidentiality of the relationship is respected. Such assurance is intended to foster the proper preparation of a lawyer to defend his client and to strengthen his legal position. Regardless of the type of information disclosed, an individual must have a particular sense of security in relation to a representative of the legal profession. This approach is a prerequisite for a properly functioning legal system and a well-protected public interest. This confidentiality is also referred to in the European nomenclature as a professional secret or as a lawyer's privilege, which is based on his obligation to keep all information disclosed by the client confidential in the context of the client-lawyer relationship. As a rule, the lawyer is required to refuse to disclose information not only to the general public but also to the court, state authority and any other institution. This rule also applies to correspondence and legal advice ${ }^{2}$. The term "professional secrecy" is commonly used in the system of continental law, while in the common law system we can expect the use of the term "attorney-client privilege".

In Europe the privilege protecting lawyer-client relationship is called the legal professional privilege - otherwise LPP. The doctrine has been first

2 Dirk Van Gerven, ed., Professional secrecy of lawyers in Europe (Cambridge: Cambridge University Press, 2013), 1-10. 
defined in $A M \& S$ a judgement in $1982^{3}$ and its scope has been clarified in Akzo Nobel Chemicals and Akcros Chemicals v Commission ("Akzo") $)^{4}$. That being said, the legal professional privilege applies only to written communications between attorneys and clients for the purpose of exercising the client's right to defense. What is more, lawyers to whom European privilege applies must be independent, which means that they are not bound to their clients by a relationship of employment. Under this ruling, there is no possibility to extend LPP to communications written by in-house lawyers, unless it is used exclusively for the purpose of legal advice from an outside lawyer in the exercise of the right of defense. What is more, the LPP applies only to an attorney that is admitted to the bar of the European Union Member State 5 .

Unfortunately, there is no uniform definition of professional secrecy in the European Union. Its concept is slightly different depending on the Member State. However, the point of reference is the idea of confidentiality, seen as essential to ensure a complete and unhindered exchange of information between the client and the legal advisor. Professional secrecy is supposed to be a guarantee, that a lawyer will not disclose it, and will not be forced to disclose information covered by professional secrecy. If such regulatory provisions are lacking, then the client will be significantly restricted in the enforcement of his rights through a suitably prepared expert. Such trimming of the information would have severely damaged the professional representation and, consequently, would not allow the individual to fully realize constitutionally guaranteed freedoms and rights.

As the definition construed by The Council of Bars of Law Societies of Europe's Code of Conduct for European Lawyers states, it is the core of a professional lawyer's job to be the recipient of the information, based on the value of confidentiality, without which there can be no trust. Maintaining specific client information in secret is, therefore, the most crucial duty of the legal profession. This serves not only to protect the interests of

3 Case C-155/79, AM \& S Europe Limited v Commission of the European Communities, $18^{\text {th }}$ of May 1982.

4 Joined cases T-125/03 \& T-253/03, Akzo Nobel Chemicals and Akcros Chemicals $v$ Commission of the European Communities, 17 $7^{\text {th }}$ of September 2007.

5 Ibid. 
the client, but also to fulfill a public role in protecting the interests of public authorities and the justice system. Confidentiality, as it serves the public interest, also benefits the protection afforded by the state ${ }^{6}$.

The privilege of confidentiality extends not only to the widely understood client-lawyer relationship, but also serves in various court proceedings. The right to a fair trial has been among others expressed in article 6 of the European Convention on Human Rights and Fundamental Freedoms. This right should be respected either when the individual is obliged to do something or when there are asserted claims. This right is construed as the right to access to the courts in both civil and criminal proceedings. Consequently, the party is also entitled to be represented by a professional representative.

The privilege also extends, as I have mentioned, to the so-called legal advice. This is due to the fact that information relating to legal advice benefits from the protection of professional secrecy. Furthermore, a Member State may exclude disclosure of information from the authorities if this information was the subject of communication with a lawyer or lawyers. It is, therefore, clear from the directive that any legal aid will be protected by a lawyer's privilege, regardless of whether that aid ultimately leads to a legal dispute. Additional reinforcement for the privilege of confidentiality may be article 8 of the European Convention on Human Rights and Fundamental Freedoms, which guarantees respect for private and family life and the secrecy of correspondence. Moreover, the European Court of Human Rights has confirmed some sufficiency of this provision as the basis for the existence and the validity of professional secrecy ${ }^{7}$.

A lawyer's privilege may be waived in a democratic state solely for the protection of public security or the national economy, as well as for the prevention of violation of law or for the protection of life, health, morals, freedoms and human and civil rights. The inclusion of the authorities in this sphere of confidentiality is admissible only, if it is consistent with the generally applicable law and is related to one of the situations mentioned above and is necessary to achieve these objectives. This necessity is defined in such a way that entering into the sphere of confidentiality

6 Supra note 34.

7 Petri Sallinen et. Al. V Finland, www.echr.coe.int/hudoc, (Apr. 23, 2015). 
will be justified under the principle of proportionality and will respond to the legitimate needs of society. Furthermore, any exceptions to the rule of confidentiality must be interpreted restrictively and the purpose of the infringement should be justified. In the opinion of the European Court of Human Rights, any correspondence also benefits from the privilege of confidentiality, and any interference in its content must be substantiat$\mathrm{ed}^{8}$. Moreover, acquiring such correspondence constitutes a violation of the lawyer's privilege and article 8 of the European Charter of Human Rights? . It should be noted that, in its decisions, the Court pointed out that even in situations where interference seems justified on the basis of an important social interest, this activity should not prejudice the lawyer's privilege. However, if such an infringement occurs, it may be possible to file a lawsuit in this case.

It is noteworthy that the conflict between professional secrecy and the public interest often occurs. The European Court of Human Rights pointed out that in such a case the balance and the appropriate proportions between the values indicated should be respected and that any restrictions of confidentiality should be applied in exceptional circumstances and only in order to protect public interest as a more important value in a particular case. Unfortunately, in European practice, the view is that a legal professional is entitled to disclose information covered by professional secrecy, if it is directed towards protection of a value defined as the highest one $\mathrm{e}^{10}$.

The Code of Conduct for European Lawyers, adopted by the Council of Bars and Law Societies of Europe on 28 October 1988 is a key act for establishing ethical rules for the exercise of the legal profession in the European Union. The Code of Ethics has been amended 3 times and the last change is dated $2019^{11}$. The text of the act is currently binding on the lawyers of all member countries regardless of the form of their association in a Member State, and the guidelines contained therein form the basis of the deontological rules for European legal professions.

8 Campbell v. UK, series A, no 137, www.echr.coe.int/hudoc, (Apr. 28, 2015).

9 Foxley v. UK, www.echr.coe.int/hudoc, (Apr. 28, 2015).

10 Ibid.

11 https://www.ccbe.eu/fileadmin/speciality_distribution/public/documents/ DEONTOLOGY/DEON_CoC/EN_DEON_CoC.pdf, accessed February 24, 2021. 
The most important for the protection of professional secrecy is Point 2.3., which covers the Confidentiality issue. Its content shows that confidentiality has been recognized as the essence of the legal profession, which the relationship with the client is based on. In the light of this rule, the lawyer must give the client a feeling that he can be entrusted with keeping confidential everything that the individual using legal services would not entrust to anyone else.

Without existence of the confidentiality, there can be no trust in the relationship between a lawyer and a client. Confidentiality is therefore the fundamental right as well as the duty of a lawyer, and the obligation to act is unlimited in time. The doctrine also points to the need to deal with this rule by those who work with a lawyer providing access to confidential data ${ }^{12}$.

Preceding the abovementioned Rule - Point 2.2 deals with the Trust, Righteousness and Honesty of a lawyer. The authors of the Code depend on the relationship between the nature of the lawyer and his or her attitude to guarantee honor, honesty and integrity as the core values of the legal profession.

In 1976, a report summarizing the position of legal professional secrecy in Europe at that time was published, known as the Edward Report. This report was revived in a way and expanded with new insights in 2003. The report stresses that there are different sources of professional responsibility in different European countries. These include in particular constitutions and statutes. The report mentions several countries in the European Union, among others: Ireland, France, Belgium, Luxembourg, Italy, the Netherlands, Germany and Denmark ${ }^{13}$.

In case law countries such as Ireland, the legal privilege of confidentiality is a rule derived from judgments as one of the fundamental features of justice and the letter of law. Professional secrecy exists for the client and

12 Charter of Core Principles of the European Legal Profession and Code of Conduct for European Lawyers, accessed February 22, 2021, https:/www.ccbe.eu/fileadmin/ speciality_distribution/public/documents/DEONTOLOGY/DEON_CoC/EN_DEON_ CoC.pdf.

13 Edward's Report, The professional secret, confidentiality and legal professional privilege in Europe, accessed April 29, 2015, http://www.ccbe.eu/fileadmin/user_upload/ NTCdocument/update_edwards_repor1_1182333982.pdf. 
may be the power of his decision repealed. As the House of Lords points out in one of its 1996 decisions, the legal privilege of confidentiality is one of the fundamental rights that derives from the rules of public policy and not merely the particular rule used in a particular case to determine which of the evidence is admissible and which information may be disclosed. Judges of the House of Lords took into account the client's right to confidential communication with his legal advisor ${ }^{14}$. In another 1999 judgment concerning the waiver of professional secrecy by the amended provisions of the Code of Civil Procedure, the court decided that such a waiver may take place only by an earlier provision, never later. Despite the strong protection of professional secrecy in the case law, in practice it began to be successively weakened. An example of the waiving of professional secrecy can be given in cases where it is necessary for a government department or government agency to disclose it. The authors of the report also point out that precisely in the system of case law the source of professional confidentiality should be sought primarily in criminal law. However, such acts also protect the rule of confidentiality. According to Section 19 of the Police Act and Evidence in criminal proceedings of 1986, a police officer is not competent to read the evidence if it has reasonable grounds to believe, that it may be covered by professional secrecy ${ }^{15}$.

To illustrate the obligation of secrecy of a lawyer, it is worth pointing out a number of European Union states covered by the report. In countries where the legal system of the continental type is in force, professional secrecy is rooted primarily in the constitution or acts of the rank of statute. An example may be France's legislation, where, in article 226-13 of the Penal Code, the legislator has placed a provision on professional secrecy: whoever is bound by professional secrecy, occupation, position or temporary assignment or assignment, discloses confidential information, is subject to penalty of deprivation of liberty for up to one year and a fine of EUR 15000.

In Belgium, Luxembourg, Italy and the Netherlands, the rule of discretion is also based on penal codes. The professional secrecy in Italy appears

14 Judgment of the House of Lords, 19 October 1995, Regina v. Derby Magistrates Court Ex Parte B.

15 Ibid. 
to be particularly well-guarded, where the Code of Criminal Procedure protects the lawyer from the obligation to testify in criminal matters in the context of professional secrecy. In Denmark, the duty of professional discretion arises directly from the law on the functioning of the judiciary (procedural part). From the point of view of weakening the protection of confidentiality in the lawyer relationship, it is worth pointing out the importance of judicial practice, where professional secrecy benefits legal protection as long as the court decides not to revoke it.

Among the countries of the European Union not covered by this report is f.e. Greece, where Article 371 of the Penal Code regulates sanctions for breach of the rules of professional secrecy. A lawyer cannot testify to circumstances covered by professional secrecy. The lawyer may be fined or imprisoned for up to one year for unlawful disclosure of a professional secret. It is a peculiar phenomenon in the context of disciplinary sanctions for similar offenses in other European countries. It is worth noting, that the negative consequences of a disciplinary offense are more likely to be related to restriction than to penalties in criminal law.

While it is irrefutable in the doctrine that the basic function of professional secrecy is to protect the right to privacy of an individual, there is a dispute as to whether the lawyer's privilege actually serves to ensure the proper functioning of the judiciary and the public interest.

As in most other European countries, the privilege of a lawyer is to protect the individual, but it does not include the right to dismiss a lawyer from professional secrecy, even though the individual himself has entrusted his representative with this confidential information. This rule applies both in civil and criminal proceedings. An interesting solution is to allow a lawyer to testify with the consent of the professional self-government. While in most European countries this is a court or other body before which the proceedings are pending, in Greece this decision remains with the appropriate executive body of the Council of Lawyers or the chairman of the Council. Exceptionally, a lawyer may be questioned in connection with the representation of the client, as long as this is the case connected with co called "important reasons". Interestingly, D. Van Gerven distinguishes in this case the situation of allowance to testify and the violation of the lawyer's privilege. While the first situation may arise, as noted above, with the consent of the relevant Council, the abrogation of the privilege of 
lawyer even in the case of said consent is unacceptable. The only limitation for this privilege seems to be Article 232 of the Greek Penal Code, which explicitly expresses the obligation to disclose relevant information to the authorities whenever they involve a crime. In addition, Article 371 paragraph 4 of the Code indicates that a breach of a lawyer's privilege will not be considered unlawful and cannot be sanctioned accordingly if it is intended to fulfill another obligation or to protect another important public or private interest that could not be achieved in a different way ${ }^{16}$. Greek lawyers, in turn, are obliged to belong to the local councils of professional councils - law councils. This, therefore, entails conducting professional activity in accordance with the Code of Professional Ethics.

In the second section of the report an attempt was made to answer the question, whether professional discretion is absolute in the countries covered. As a rule, in most EU countries, the bar is limited. Only Iceland, Spain and Liechtenstein have admitted that its protection is absolute. The third part of this report deals with the directions of the development of professional secrecy. The authors of the report agree that during the twenty-five years of its functioning in the European Union, the aim was rather to significantly limit the protection of professional secrecy. Corruption, drug-related crime and terrorist attacks intensified in recent years has had a huge impact on this.

At the end of the deliberations on professional secrecy in EU law, it is worth mentioning that any qualified lawyer in the European Union who meets certain requirements may become a so-called community lawyer. This is made possible by Directive 98/5 / EC of the European Parliament and of the Council, which aims to facilitate practice of the profession of lawyer on a permanent basis in a Member State other than that in which the professional qualifications were obtained ${ }^{17}$.

16 Ibid.

17 Directive 98/5/EC of the European Parliament and of the Council of 16 February 1998 to facilitate practice of the profession of lawyer on a permanent basis in a Member State other than that in which the qualification was obtained. 


\section{LEGAL AND ETHICAL GROUNDS OF PROFESSIONAL SECRECY OF A LAWYER IN THE UNITED STATES OF AMERICA}

The basis of the existence of a lawyer's secrecy in the United States legal system is certainly confidentiality. Confidentiality is, in turn, one of the principles of a client-lawyer relationship and includes the following legal aspects: the attorney-client privilege, the work-product doctrine, and the rule of confidentiality. Both the attorney-client privilege and the principle of secrecy of information obtained from the client are the rules applicable in the court proceedings, where a legal professional can be called upon to be a witness.

It is necessary to distinguish frequently confused confidentiality from the rule of confidentiality. Confidentiality is an idea in which the above-mentioned principles of attorney practice are established in the United States system of law, whereas the confidentiality principle is only one of them and has a different source and scope than the other two. The rule of confidentiality is rooted in legal ethics and requires the attorney to keep everything he learned in relation to client representation confidential. On the other hand, the attorney-client privilege, while enjoying the protection provided by the deontological rules, is primarily a product of common law and guarantees protection of the content of communication between a lawyer and a client, but does not include commonly known facts and information ${ }^{18}$.

It is also worth noting that the primary difference between the attorney-client privilege and the work-product doctrine is the value and purpose of the confidentiality of the information. An attorney-client privilege protects this part of the content of the communication that directly affects the resolution of the dispute and is used against the opponent, which in the latter case is extremely rare. It may be considered that the principle of secrecy of information obtained from a client is protected by its content, while the attorney-client privilege - despite its content ${ }^{19}$.

18 Edward J. Krauland and Troy H. Cribb, "The attorney-client privilege in the United States. An age-old principle under modern pressure," Symposium Issue of The Professional Lawyer 37 (2003): 3.

${ }_{19}$ KWMuth Co. v. Bing-Lear Mfg. Group L.L.C., 219 F.R.D. 554, 566 (E.D. Mich. 2003). 
The so called called "in-house privilege" may also be an aspect worth mentioning here.

Whether privilege protects an in-house lawyer's communications depends on the primary intention of the communication. If the objective is legal advice, then the communication is privileged, as long as it is confidential, taking into account lawyer-client relationship. Alternatively, if the lawyer is acting as a business negotiator or advisor - as the in-house lawyers frequently have multiple roles - then the communication may not be privileged ${ }^{20}$.

Despite the importance of all aspects of confidentiality in the scope of the lawyer's secrecy, for the purposes of the comparative law of this trial, I focus mainly on the principle of confidentiality and the privilege of lawyers.

As I have mentioned, the source for the first aspect of legal confidentiality in the United States is legal ethics. Because of its importance in the legal profession in the United States, reflections on its significance and evolution are worth mentioning here.

In modern democratic societies, whose functioning is based on the law in force, lawyers play an important role as guardians of justice as well as human rights and fundamental freedoms. Representatives of the legal professions have a special responsibility to maintain an adequate standard of justice. The basis of this responsibility lies in the rules of professional ethics, the observance of which is their duty to the client, the judiciary and society as a whole. The rules of professional etiquette reveal their presence in both the law and the custom, rules of law practice, and in judicial decisions.

It is impossible to overlook the importance of the US Constitution, which may also be the source of these regulations, as found in the Sixth Amendment, in which each defendant has the right to be represented by a lawyer and, in the case of ineffective representation, the amendment provides the basis for professional liability. In addition, the First Amendment guarantees freedom of expression, which enables the lawyer to seek the cli-

20 https://www.americanbar.org/groups/intellectual_property_law/publications/ landslide/2017-18/november-december/attorney-client-privilege-inhouse-counsel/, accessed February 22, 2021. 
ent and advertise his services. The clause of the appropriate legal procedure in the Fourteenth Amendment is a specific impediment to the conduct of the prosecutor and the professional liability body.

The principal and direct source of the deontological duties of lawyers in the United States is the Model Rules of Professional Conduct ${ }^{21}$. This is a set of rules of conduct of representatives of legal professions, accompanied by a commentary. The authors of the codex, however, have stated that, in view of the abstract nature of the moral principles, lawyers may have problems with their interpretation and implementation in specific situations. To this end, special institutions are set up in each state to answer questions from the legal professionals at all times. They create state committees or local law councils. For example, the New York State Local Council supported the creation of a Professional Ethics Commission, where lawyers can direct written inquiries.

As noted by J. B. Brooks, both legal professions and local councils show great interest in building the values that underpin legal professions. They notice the importance of the legal profession and therefore seek to increase the ethical requirements ${ }^{22}$.

The author stresses that the implementation of these ideas is certainly supported by legal acts or deontological codes, as they set the rules and sanctions for their violation. However, shaping the ethical values of a future lawyer should take place at the stage of university education, in which young adolescents develop moral attitudes. He also criticizes the lack of professional ethics lectures in some American colleges, which results in incomplete education in the legal profession. From reflections of J.B. Brooks it can be inferred, that for possible deontological shortages in education he blames the higher education system, not the trainees themselves.

The deontological rules define the moral rules of behavior, whose calculation can be found in the widely understood literature.

21 https://www.americanbar.org/groups/professional_responsibility/publications/ model_rules_of_professional_conduct/model_rules_of_professional_conduct_table_of_ contents/, accessed February 22, 2021.

22 James B. Brooks, "Legal ethics," The Yale Law Journal 19, no. 6 (1910): 1-10. 
As W.H. Simon states, the legal professionals should act in such a way as to promote the idea of justice ${ }^{23}$. In turn, D. Luban advises lawyers to guard against human dignity rather than destroy $\mathrm{it}^{24}$. As noted by S. Pepper, lawyers should provide clients with access to the legal acts on which they base their actions and refrain from moral judgments about their clients' affairs and actions ${ }^{25}$. According to C. Fried, the most important value of a lawyer in relation to a customer is loyalty, which should be displayed at every opportunity and regardless of the client's needs. The interest of the individual is to be a priority for the lawyer higher than the interest of the general public ${ }^{26}$.

In the literature it is also noted that a lawyer, by providing legal advice, should openly express his moral values ${ }^{27}$, which is a manifestation of the integrity of the client. Moreover, too little attention is paid to legal ethics in the context of the legal profession itself and, above all, the individual characteristics of the profession: talent to practice, temperament, values. It is noteworthy, that the human personality is not plastic and can be molded by the law, and the deontological principles should be expressed in the form of psychologically-contained rules, which will allow an answer not only to the question "what lawyer should do?". But also "what lawyer should be?". The aim of these rules is to answer the question: "Who can be called a perfect lawyer?". In addition to determining the typical moral characteristics, that a lawyer should possess, it is worthwhile to work out specific responses such as: no negative reaction to criticism or satisfaction with representation of the injured client ${ }^{28}$.

23 William H. Simon, The practice of justice: A theory of lawyer's ethics (Cambridge: Harvard University Press, 1998), 138.

24 David Luban, Legal ethics and human dignity (Cambridge: Cambridge University Press, 2007), 66.

25 Stephen Pepper, "The lawyer's amoral ethical role: A defense, a problem, and some possibilities," Legal Research Paper Series 11, no. 4 (1986): 613-617.

26 Charles Fried, "The lawyer as a friend: The moral foundations of the lawyer-client relation," The Yale Law Journal 85 (1976): 1060-1066.

27 Robert K. Vischer, "Legal advice as moral perspective," Georgetown Journal of Legal Ethics 19, Issue 1 (2006): 225-229.

28 Alasdair Macintyre, After virtue: A study in moral theory, $3^{\text {rd }}$ ed. (Notre Dame, Indian: University of Notre Dame Press, 1981), 171. 
A slightly different view is presented by G. Postema, who claims that the requirement for a lawyer to obey different rules puts him in an uncomfortable position, which involves oscillating between strictly professional and moral instructions. Since professional instructions are strictly defined, measurable, and thus affecting the evaluation of the work performed, the lawyer will show, according to the author, a tendency to reject moral rules, and even a cynical approach to them ${ }^{29}$.

Despite the emerging doubts in the doctrine as to the correctness of establishing specific moral rules, the vast majority of the $\mathrm{ABA}$ act is considered to be the closest to the ideal, as already mentioned, Model Rules of Professional Conduct. Although, in its content there is no direct mention of human rights, this act is undoubtedly based on them, since they constitute the basis for the development of moral rules in order to manage the behavior of the state as the authority, the society and the individual as well. By comparison, professional ethics standards focus on individual decision. However, both have a common source of mechanisms for the implementation of moral rules. Both norms derived from human rights and those based on professional ethics, as the chief rule in contacts lawyer-client, consider dignity as the main rule in lawyer-client relations ${ }^{30}$.

The first nationwide law regulating professional ethics, issued by the American Bar Association in 1908, Canons of Professional Ethics, has remained in power for over 60 years. Thirty-two of these principles were based on the Code of Professional Ethics established by the Alabama Board in 1887. This, in turn, was borrowed from George Sharswood's lectures, published in 1854, Professional Ethics and from David Hoffman's 1836 reflections contained in the Legal Studies. Both the Supreme Court and members of the ABA Commission for Legal Acts recognized canons from 1908 as a great achievement due to their compactness, clarity, precision and elaboration in a way that did not allow for frivolous breaches of professional ethics ${ }^{31}$. The canon law was concerned primarily with the maintenance of unity and impartiality in the administration

29 Gerald J. Postema, "Moral Responsibility in Professional Ethics," New York University Law Review 55 (1980): 77-82.

30 Luban, Legal ethic, 65-95.

31 Ibid., 160. 
of justice as the "cornerstone of democracy". These ethical rules came at the right moment and were a response to President Roosevelt's famous speech at a Harvard University meeting in 1905, where he accused the legal profession of abandoning moral values to pursue the lucrative undertakings of large corporations. This statement led to the ABA Committee meeting in 1906 to prepare a draft of a set of ethics rules. It is assumed that without the networks of law firms, for whom the economic outcome was more important than the moral principles and the critical attitude of the then-president, perhaps codes of professional ethics would never have been created ${ }^{32}$.

The Canons have been changed many times over the past 60 years, however, these modifications were chaotic and disorderly, but also random and fragmentary. A new perspective on the rules of professional ethics was proposed by L. Powell - ABA president, then appointed as a judge of the Supreme Court. Thanks to his initiative, steps were taken to create a Special Committee on Ethical Standards to evaluate the performance of the legal profession in the United States in terms of moral rules. The Committee, however, was, first of all, to propose a radical change to the Canons $^{33}$. Five years later, in 1969 ABA accepted the Committee recommendation and adopted the Model Code of Professional Responsibility. While the Canons were a relatively short list of the most important principles of professional ethics, the Code laid down detailed rules of conduct, taking into account contemporary law practice, and disciplinary rules. In addition, unlike the Canons, which did not explicitly refer to human rights, the concept of human dignity, the dignity of the individual, emerged in the Code of Professional Responsibility. In the Preamble of the Code there is such a direct reference: the existence of a free and democratic society is based on the belief that justice comes from the letter of law and respect for the dignity of the individual and his self-government. It is highly probable

32 Ibid., 162.

33 see: Michael S. Ariens, "American legal ethics in an age of anxiety," St. Mary's Law Journal 40, no. 2 (2008): 430; Center for Professional Responsibility, A legislative History: The Development of the ABA Rules of Professional Conduct 1982-2013 (Chicago: American Bar Association Book Publishing, 2013), vi-viii. 
that this sentence comes from talks conducted at this time in the international arena.

For example, the International Covenant on Civil and Political Rights, adopted in 1966 by the UN General Assembly, just three years before the adoption of the Code, indicates that dignity and equality in law are intrinsic values of every human being and the basis of freedom, justice and peace in the world. Apart from the appearance of the concept of dignity in the Preamble, the Code did not directly invoke human rights anywhere in the act, and it treated morality less expansively than in the case of the Canons. In this act, morality was invoked in relation to justice and the higher goals of the legal profession, while the Code equates this value with refraining primarily from lies and theft.

The current act, which is a deontological set for American lawyers, is called the Model Rules of Professional Conduct and was last amended in April $2020^{34}$. Although they are not binding law, they are intended to be a particular model for state regulators - all fifty states with District Columbia have adopted ethic rules to a similar extent - to form consistent rules for practicing the legal profession

Returning to the consideration of professional secrecy in practicing the profession of lawyer in the United States, it should be emphasized once again that the rule of confidentiality is primarily an ethical obligation for a lawyer, as stated in section 1.6 of the Model Rules of Professional Conduct. The scope of this rule is much broader than the scope of the attorney-client privilege, as it covers everything the lawyer has learned in connection with legal advice. In the light of this rule, a lawyer is not allowed to disclose information obtained in connection with the representation of the client, unless the client agrees or the disclosure of information is a prerequisite for an adequate and effective defense of his interests or if the provisions of the MRPC allow it. The scope of the confidentiality rule is clearly defined and delineates the boundaries around information that is relevant to representation, and therefore anything that could have any connection with the case conducted by a lawyer. In addition, the ex-

34 https://www.americanbar.org/groups/professional_responsibility/publications/ model_rules_of_professional_conduct/, accessed February 22, 2021. 
ceptions to this rule are interpreted by the courts narrowly, and in case of doubt - in its favor ${ }^{35}$.

Attorney-client privilege is the oldest of the evidential privileges that protect the confidentiality of information. It was recognized and used during the reign of Elizabeth I. At that time, its purpose was to prevent the taking of oaths and testify against a person using legal services. It was believed that such testimony, taking into account the need to maintain loyalty to the client, would have been a stain on the attorney's honor and taken to him as a gentleman. In those days, however, the privilege was granted to him, not to the person to whom he provided services, and in fact he had little in common with the present privilege ${ }^{36}$. Nowadays, the privilege is the prerogative of the client. He is, therefore, not the lawyer, entitled to it - he can raise it and revoke it.

Fundamental acts, which are the source of the attorney-client privilege, are the Rules of Evidence - both at the federal and state level. Federal Rules of Evidence apply and are enforceable by federal courts, while State Evidence Rules are enforceable in individual states. Due to the fact that in most states of the United States the attorney-client privilege in the evidence law is similar to the federal law, it was precisely the provisions of the evidence law at the national level that I used as the basis for consideration.

The existence of evidence privileges in law is in constant opposition to the main goal of the trial, which is to establish the truth, and any protection of essential information from disclosure must be very clearly outlined. Confidentiality is an exception in the Anglo-American law that requires anyone who has the knowledge to disclose the content of the process necessary to achieve the objectives of the process. The application of this rule is further treated as a realization of the public interest, which leads to the resignation from the suppression of truth, which in turn is the purpose of the privilege itself. The attorney-client privilege should be applied within the limits of the assumption that it represents and cautiously enough

35 Susan P. Koniak, "The law between the Bar and the State," North Carolina Law Review 70, no. 5 (1991): 1431-1432.

36 Ibid., 60 . 
to minimize the achievement of procedural objectives ${ }^{37}$. In American doctrine, it is noted, that the fundamental right of an individual is unlimited access to any existing evidence. The basic premise is the existence of a general obligation to testify about everything that is known to the witness in a given case, and any exceptions to this rule should be applied in a clearly exceptional manner. This view was confirmed by the Supreme Court, among others. in the 1950 and 1974 judgments, stating that exceptions to the rules of evidence in law should be taken into account in a prudent and restrictive manner, as they impede the determination of truth in a trial, and thus infringe the principle of substantive truth ${ }^{38}$.

Despite the existence of the principle of narrow application of the attorney-client privilege, it turns out that courts do not always comply with it. On the one hand, there is a need to disclose in the process all relevant facts. On the other hand, the need to protect the confidentiality of the client's relationship with the lawyer is increasingly recognized ${ }^{39}$. It is important to maintain a balance between these values. Introducing such a balance in the process, in my opinion, inevitably strengthens the position of the attorney-client privilege as an exception to the procedural rule of striving to establish the truth.

In 1996, the Supreme Court warned federal courts to use the attorney-client privilege in a restrictive way and did not extend its scope or create new privileges ${ }^{40}$. It is worth noting that in legal practice it often happens that lawyers are surprised at how narrowly outlined the attorney-client privilege is, forgetting that it is not absolute.

The scope of the attorney-client privilege is, as I said, relatively narrow. It protects the communication between the lawyer and the client. As the Supreme Court of the United States stated in its 1992 ruling, also silence or concealment may be acts of privilege. An example of such a situation may be, for example, tacit consent expressed by not submitting

37 John H. Wigmore and John T. McNaughton, Evidence in trials at common law (Boston: Little, Brown and Company, 1961): 400-450.

38 see: United States v. Bryan, 339 U.S. 323 (1950); United States v. Noxon, 418 U.S. 683 (1974).

39 Edna S. Epstein, The attorney-client privilege and the work-product doctrine (Chicago: American Bar Association Book Publishing, 2007), 13.

40 Jaffee v. Redmond, 518 U.S. 1. (1996). 
an objection, or the act of nodding the head as a sign of accepting a proposal $^{41}$. The privilege, however, does not protect the information contained in the content of that communication. Therefore, while the very core of information is not protected, the so-called "surroundings" - such as the opinions provided by the client about this information - is already covered by the protection ${ }^{42}$. Moreover, the information itself does not acquire the character of protected communication from the fact of its analysis or paraphrasing by a lawyer or client ${ }^{43}$. It is worth noting, however, that the very fact of providing this unprivileged information to the lawyer remains under protection. Consequently, in a situation where the client communicates with a lawyer in connection with a given case and at the same time consults an advisor from another field (e.g. a tax advisor) in the same matter, the content of the communication remains privileged ${ }^{44}$.

The constantly evolving jurisprudence is essential in assessing the scope of the legal privilege in question. The courts are willing to extend the scope of its application to any legal advice the lawyer has provided to the client in connection with mutual communication, which is contrary to the historical perception of a privilege which, from the outset of its identification in Anglo-American law, protected legal advice exclusively in a derivative manner and therefore only to the extent that this advice coincides with the previously obtained content of the privileged communication ${ }^{45}$.

Currently, as I mentioned earlier, the attorney-client privilege, paradoxically, does not belong to the lawyer, but to the client. Nevertheless, due to the fact that the client is often a layman, unaware of the nuances of the functioning of the privilege and its proper enhancement, it is possible for a lawyer to raise the privilege on his behalf. In practice, therefore, the lawyer has a privilege that is still the exclusive right of the individual using his services.

Therefore, in a situation where the services of a lawyer are used by one person, the decision on whether to increase the privilege belongs to

\footnotetext{
41 U.S v. White, 970 F. 2d 328, 334, 36 Fed. R. Evid, Serv. 657 (7th Cir. 1992).

42 U.S. v. James, 708 F.2d, 40, 44 n.3 (2d Cir. 1983).

43 Colton v. U.S., 306 F. 2d 633, 639 (2d. Cir. 1962).

44 Willnerd v. Sybase, Inc. 2010, West Law: 5391270.

45 U.S. v. Rakes, 442 F. $3 \mathrm{~d}$ (1st Cir. 2006).
} 
him. A possible conflict may arise only when such a right is held by several people, some of whom want to keep the attorney-client privilege in force, and the rest want to revoke it. An example is the situation where - in the case of representing a company - its representative may waive the attorney-client privilege, even if his predecessors had a different view on this matter. Another important example is the possibility of raising or revoking the privilege by the legal successor of the authorized entity. American case law recognizes such as, for example, a bankruptcy trustee ${ }^{46}$. In the event that control of the firm is transferred to a new management group, the authority of the privilege is also transferred to the new entity. Despite the above, in the case of purchasing an enterprise, the privilege does not become the buyer's right. In the light of the current case law, it cannot be sold as it does not belong to any category of assets ${ }^{47}$.

It seems obvious that anyone who can raise a privilege can also revoke it. In the Grand Jury proceedings it was ruled in 1977 that the attorney-client privilege belongs to the client and not to a lawyer who cannot withdraw or revoke it, even if the will of the represented individual is against $\mathrm{it}^{48}$. In situations where the client explicitly forbids lawyer from disclosing privileged information, such disclosure will be ineffective. Consequently, the content of the communication will not be able to serve the purpose for which it was disclosed. It is true, however, that once disclosed information is already in the consciousness and memory of those who have access to it. Therefore, any cases of the so-called inadvertent disclosure of information covered by the privilege cannot be a pretext for using it, if the client to whom the privilege belongs does not consent to its use $e^{49}$. Although the attorney-client privilege belongs to the client, it is de facto the lawyer who raises it on behalf of and for the represented entity, also in the absence of the client. There is an assumption in United States case law that a lawyer, even in the absence of expressed instructions from the client, will adequately use the privilege on his behalf. If, however, the client questions the lawyer's right to act within the scope of the privilege, he must express

46 CFTC v. Weintraub, 471 U.S. 343 (1985).

47 Zenith Electronics Corp. v. WH-TV Broadcasting Corp., 395 F.3d 416, 420 (7th Cir. 2005).

48 In re Grand Jury Proceedings, 73 F.R.D. 647 (M.D Fla. 1977).

49 United States v. Camacho, 368 F3d 1182, (9th Cir. 2004). 
such will clearly. Otherwise, all actions of the lawyer aimed at waiving the attorney-client privilege on behalf and for the benefit of the client will be considered valid ${ }^{50}$.

In some cases, there may also be a conflict between the former and the current legal representative when summoned by the court to increase the bargaining power of the lawyer in the absence of the client. As the New York Court of Appeals noted in 1982, a prudent lawyer should act very cautiously, given that any action to disclose information that is subject to a privilege may be viewed as a form of waiver. As the privilege may in this case lose its validity, the prudence requires that the lawyer undertake only those actions that will not lead to involuntary and unintentional disclosure of confidential information ${ }^{51}$.

As noted by J.H. Wigmore, four conditions should be indicated, which - if met cumulatively - give the possibility of recognizing the evidential privilege: the communication between the client and the lawyer must be based on the assumption and the expectation that it will remain confidential. Confidentiality is a prerequisite for building the right, satisfactory, and effective relationship between the client and the lawyer. The indicated legal representation must meet, according to the opinion of the society, the conditions of a relationship requiring special legal protection. The damage resulting from the disclosure of the confidential content of the communication between the client and the lawyer must outweigh the benefits of waiving the privilege to resolve the dispute $e^{52}$.

As noted by the Massachusetts State Court, only full and unrestricted knowledge of all facts can be the basis of an appropriate and valid legal service. Otherwise, the value of such service is questionable. In addition, the public good, resulting from an adequate, trustworthy representation of the client by a lawyer, overrides any possible detriment to the course of the trial, resulting from the non-admission of the evidence in question by the court ${ }^{53}$.

50 United States v. Bump, 605 F.2d 548 (10th Cir. 1979).

51 Schnell v. Schnall, No. 80 Civ. 2442 (GLG), 550 F. Supp. 650 (S.D.N.Y 1982).

52 Wigmore and McNaughton, Evidence in trials, 520-530.

53 United States v. United Shoe Machinery Corporation, 89 F. Supp. 349 (D. Mass 1950). 
Another justification for the existence of the abovementioned conditions is that, by promoting full freedom in communication, the privilege supports voluntary subordination, thereby fostering effective enforcement. The ultimate consequence of not upholding unfettered freedom of communication is providing untrustworthy legal advice and the inability to direct the client's intentions in a way that enables him to act in accordance with applicable law ${ }^{54}$.

As stated by the Court in its ruling from 1981, in order to ensure the compliance of legal services with the law, it is necessary to cover them with full protection against disclosure. At present, the privilege protects not only the content of the communication from the client to the lawyer, but also the content of legal advice provided by the client ${ }^{55}$. It is important not only for the participants in the relationship, but also for the public to communicate in the course of the provision of legal services in confidence. The privilege itself is more effectively exercised by the lawyer himself, if his knowledge of the structure of the privilege is greater than that of the client. The doctrine also notes that bidirectionality of the privilege allows for easier understanding of its rules by a layman, for the clarity of its use by a lawyer, and the accessibility of its use by courts ${ }^{56}$.

J.H. Wigmore assessed all evidence privileges in a utilitarian manner. By analyzing the attorney-client privilege, he considered whether in fact the necessity of covering a given content with a privilege was more important than establishing the truth in the court proceedings. The view expressed in doctrine and jurisprudence is that the evidential privileges are a realization of the right to privacy, which, with a few exceptions, must be respected and legally protected. These rules indicate that a lawyer cannot disclose the contents of the information entrusted by the client to the court in the event of disclosure. As such, the American Bar Association has repeatedly suggested that the privilege should include the name client-attorney privilege instead of attorney-client privilege, thus indicating the prin-

54 Natta v. Hogan, 392 F. 2d 686. (1986).

55 Upjohn Co. v. United States, 449 U.S. 383 (1981).

56 Edna S. Epstein, The attorney-client privilege and the work-product doctrine (Chicago: American Bar Association Book Publishing, 2007), 9. 
cipal subject to whom it applies ${ }^{57}$. The practical consequence of the use of the privilege is that there is no compulsory or voluntary disclosure of any information that the client has given secretly to an attorney for legal advice. The privilege, therefore, functions in opposition to coercion and, in addition, functions in two directions: it protects both "spoken word" and "written word" coming from the client or directed to him. The justification for its existence in the legal order is the need to preserve the acquired information in confidence in order to provide effective legal advice. If, therefore, the client receives legal advice in the belief that his openness will be used against him in the future, the legal advice provided will be based on a half-truth, which may in turn result in non-compliance ${ }^{58}$. The $\mathrm{Su}$ preme Court of the United States also noted that the confidentiality of a client-lawyer relationship is a guarantee of safe and appropriately granted legal advice, and that, securing a certain entity from infringing its personal rights, it protects the interests of the public and the whole of justice ${ }^{59}$. Despite the fact that the privilege is a prerogative of the client, a legal professional must inform the individual of his ability to use it and protect it by using his knowledge and professional practice.

\section{CONCLUSION}

Confidentiality of client communications, loyalty and integrity are kind of the anchor of the attorney's confidentiality - as a value - in both the European Union and the United States. Certainly, there are similarities and differences with reference to ethical regulations in civil law and common law systems. An attorney`s obligations of confidentiality is a core of the client-lawyer relationship and is supported with ethical rules regulating legal profession in both compared systems. Without an adequate safeguarding of the value of trust, the client is not able to fully and sufficiently provide information relevant to the defense of his interests. Therefore,

57 Ibid.

58 Fisher v. United States, 425 U.S. 391 (1976).

59 Hunt v. Blackburn, 127 U.S. 774 (1888). 
the individual cannot be sure that the lawyer will represent him effectively, knowing all the necessary details.

In the US, attorney-client privilege applies to any communication between client and a lawyer for the aim of providing legal services in terms of his employment. The protection does not, however, include either the communication if the third party is involved or non-legal roles of the lawyers. Moreover, the privilege does not cover the intention to commit crime and fraud.

In the EU countries Legal Professional Privilege covers written communications concerning the right of defense, including documents prepared exclusively for the aim of seeking legal advice. In both cases, the privilege is applicable at the time, when legal advice is sought or received. As for the written ethical rules, common law codes are more formal and constitute rules rather than standards, while the EU codes are shaped in more general terms.

The construction of the privilege serves similar but not identical purposes in both systems. While in the United States the privilege is set to encourage full and frank communication between lawyers and their clients, In EU countries it mostly exists to protect client`s right of defense. First of all, in the United States the court cannot force lawyers to disclose information obtained through communication with their client. This is the price the American system pays for the protection of the individual's privacy. Increased protection of the secrecy is thus at the expense of the justice system. Neither the client nor the lawyer can be penalized for refusing to disclose the data indicated. If, despite the above, the court order forces the attorney to disclose the privileged content of the communication, it is possible to file a motion in a separate proceeding for the annulment of the judgment, by which the court made the order ${ }^{60}$. At times, however, the courts try to circumvent the privilege, by seeking, at all costs, the grounds for a disclosure or, in other words, for giving up or for inadvertent disclosure, which for them is a certain loophole for the implementation of the principle of seeking truth in a trial. The occurrence of the indicated cases of disclosing a secret by the interested

${ }^{60} \mathrm{http}: / / \mathrm{nnedv}$.org/downloads/NNEDV_CI_Primer_on_Privilege_2015.pdf, accessed March 2, 2020. 
person himself, even when it is done unintentionally and accidentally, results in waiver of the privilege. Any disclosure of information protected by a privilege to unauthorized persons leads to the loss of the protection granted by the privilege. Therefore, both the lawyer and his client must be careful not to make the privilege lose its force by reckless action. A European privilege, in turn, may be waived in a democratic country merely for the protection of public security or the national economy, as well as for the prevention of violation of law or for the protection of life, health, morals, freedoms and human and civil rights. The engagement of the authorities in this sphere of confidentiality is admissible only, if it is coherent with the generally applicable law and is connected with one of the situations mentioned above and is necessary to achieve these aims. In other words, the infringement of the sphere of confidentiality will be legitimate and rationalized only under the principle of proportionality and will respond to the legitimate needs of society. Moreover, any exceptions to the rule of confidentiality must be interpreted restrictively and with the justification of such "violation".

The most important difference in the structure of the privilege is the specific power over it. While in the European Union it is essentially the privilege and management it belongs to the lawyer, in the US it is in the client's possession. It seems that it is the American structure of the privilege that brings the institution of confidentiality closer to the ideal. It is the essence of the principle of freedom, which should be a priority in this type of relationship. In my opinion, this rule is also more honest - the individual has self-determination according to his own needs, but also bears the consequences of his actions. Moreover, on the basis of this system, it is unacceptable to waive the legal secrecy for the benefit of the administration of justice. In American jurisprudence, such proceedings would be regarded as an admission to the weakness of the justice system and its methods of obtaining evidence. The protection of the confidentiality of an individual in law is the effect of a compromise between private and public interest. Therefore, reconsideration of the hierarchy of these goods cannot take place. It should be noted that US legal secrecy is not absolute, but the courts are reluctant to revoke it in the process.

In my opinion, European laws could be inspired by some of the indicated regulations of American law, serving - through this - to improve 
the institution of professional secrecy in the performance of the lawyer profession, and thus the well-being of individuals as well as the common good of society.

\section{REFERENCES}

Ariens, Michael S. "American legal ethics in an age of anxiety." St. Mary's Law Journal 40, no. 2 (2008): 343-454.

Brooks, James B. "Legal ethics." The Yale Law Journal 19, no. 6 (1910): 1-10.

Center for Professional Responsibility. A legislative History: The Development of the ABA Rules of Professional Conduct 1982-2013. Chicago: American Bar Association Book Publishing, 2013.

Epstein, Edna S. The attorney-client privilege and the work-product doctrine. Chicago: American Bar Association Book Publishing, 2007.

Fried, Charles. "The lawyer as a friend: The moral foundations of the lawyer-client relation." The Yale Law Journal 85 (1976): 1060-1066.

Koniak, Susan P. "The law between the Bar and the State." North Carolina Law Review 70, no. 5 (1991): 1431-1432.

Krauland, Edward J., and Troy H. Cribb. "The attorney-client privilege in the United States. An age-old principle under modern pressure." Symposium Issue of The Professional Lawyer 37 (2003): 2-15.

Luban, David. Legal ethics and human dignity. Cambridge: Cambridge University Press, 2007.

Pepper, Stephen. "The lawyer's amoral ethical role: A defense, a problem, and some possibilities." Legal Research Paper Series 11, no. 4 (1986): 613-617.

Macintyre, Alasdair. After virtue: A study in moral theory. $3^{\text {rd }}$ ed. Notre Dame, Indian: University of Notre Dame Press, 1981.

Postema, Gerald J. "Moral Responsibility in Professional Ethics." New York University Law Review 55 (1980): 77-82.

Simon, William H. The practice of justice: A theory of lawyer's ethics. Cambridge: Harvard University Press, 1998.

Van Gerven, Dirk, ed. Professional secrecy of lawyers in Europe. Cambridge: Cambridge University Press, 2013.

Vischer, Robert K. "Legal advice as moral perspective." Georgetown Journal of Legal Ethics 19, Issue 1 (2006): 225-229.

Wigmore, John H., and John T. McNaughton. Evidence in trials at common law. Boston: Little, Brown and Company, 1961. 
